\title{
KADAR PEROKSIDA LIPID DAN AKTIVITAS SUPEROKSIDA DISMUTASE SERUM DARAH PADA PENDERITA DIABETES MELITUS TIPE 2
}

\author{
Heni Kristina, ${ }^{1 *}$ Nurmasari Sartono ${ }^{1}$ dan Rusdii ${ }^{1}$ \\ ${ }^{1} J u r u s a n$ Biologi FMIPA Universitas Negeri Jakarta (UNJ). Jl. Pemuda No. 10 Rawamangun, Jakarta Timur. \\ 13220. Indonesia. \\ *Email: henikristina@hotmail.com
}

\begin{abstract}
Prevalence of type 2 diabetes mellitus rapidly increase in industry and developing country. Oxidative stress was estimated has role in development of type 2 diabetes mellitus. This study was aim to measure levels of malondialdehyde (MDA) and activity of superoxide dismutase (SOD) in type 2 diabetes mellitus, and also to analyse the relationship among both. This study was conducted on July-October 2014, using Ex Post Facto method and cross sectional design. The result showed that MDA serum levels significantly higher in diabetes mellitus patient compare to normal $(P=0,000)$. Activity of superoxide dismutase (SOD) in diabetes mellitus serum has no significant difference with normal $(P=0,290)$. There was possitive correlation between levels of MDA and activity of SOD in type 2 diabetes mellitus but not significant $(P=0,478)$ with $r s=0,199$, thus also in normal subject $(P=0,194)$ with $r s=0,355$. There was no significant different between two correlation coefficient $(P=0,6781)$. In conclusion, there was significant different level of MDA, there was no significant different activity of SOD, there was positive correlation but not significant between levels of MDA and activity of SOD serum in type 2 diabetes mellitus and normal. And there was no significant different between two correlation coefficient.
\end{abstract}

Keywords: malondialdehyde, superoxide dismutase, type 2 diabetes mellitus

\section{PENDAHULUAN}

Diabetes melitus merupakan masalah kesehatan utama di seluruh dunia. Diabetes melitus adalah kelompok penyakit metabolik yang ditandai dengan hiperglikemia akibat dari adanya gangguan sekresi insulin, aktivitas insulin, atau keduanya (Kangralkar et al., 2010). Hiperglikemia merupakan keadaan dimana kadar glukosa didalam darah tetap tinggi karena tidak dapat masuk kedalam sel. Sekitar 90-95\% penderita diabetes termasuk dalam diabetes melitus tipe 2, yang merupakan jenis paling umum dari diabetes (Kumawat et al., 2009). Berbagai penelitian menunjukkan adanya kecenderungan angka insiden dan prevalensi diabetes melitus meningkat di berbagai penjuru dunia. Prevalensi diabetes melitus, khususnya diabetes melitus tipe 2 dengan pesat meningkat di negara-negara industri dan berkembang. Prevalensi diabetes melitus di Indonesia mencapai jumlah 8.426 .000 pada tahun 2000 dan diperkirakan akan mencapai 21.257.000 pada tahun 2030 (Bustan, 2007).

Patogenesis diabetes melitus tipe 2 ditandai oleh gangguan metabolik yakni adanya penurunan respon jaringan periferal dalam merespon insulin (resistensi insulin) (Kangralkar et al., 2010). Kerusakan pada jaringan periferal diduga akibat dari adanya peningkatan radikal bebas didalam tubuh, yang merusak reseptor insulin atau transporter glukosa yang terdapat pada membran sel. Radikal bebas yang ada di dalam tubuh dihasilkan oleh 
proses metabolisme sel normal (Moussa, 2008). Tanpa disadari, dalam tubuh terbentuk radikal bebas secara terus menerus baik melalui proses metabolisme sel normal maupun dari faktor luar. Kedua faktor tersebut secara sinergis meningkatkan jumlah radikal bebas dalam tubuh (Winarsi, 2007). Radikal bebas dalam jumlah yang berlebih akan mengoksidasi dan menyerang komponen lipid membran sel sehingga terjadi peroksidasi lipid (Widia, 2009). Seiring dengan meningkatnya radikal bebas, maka peroksidasi lipid membran sel juga meningkat yang menghasilkan produk akhir berupa Malondialdehida (MDA). Untuk meredam kerusakan yang diakibatkan radikal bebas diperlukan antioksidan (Setiawan et al., 2005). Secara alami di dalam tubuh terdapat sistem pertahanan antioksidan enzim seperti superoksida dismutase (SOD), katalase, dan glutation peroksidase. Berdasarkan studi terdahulu dilaporkan bahwa superoksida dismutase (SOD) merupakan garis pertahanan terdepan terhadap senyawa radikal bebas (Alvarez, 1987). Antioksidan ini berperan dalam mengubah anion superoksida $\left(\mathrm{O}_{2}\right)$ yang merupakan

inisiator kuat berbagai reaksi berantai menjadi oksigen $\left(\mathrm{O}_{2}\right)$ dan hidrogen peroksida $\left(\mathrm{H}_{2} \mathrm{O}_{2}\right)$ yang bersifat lebih stabil dibandingkan superoksida.

Dalam keadaan normal terdapat keseimbangan yang tepat antara radikal bebas dan antioksidan. Meskipun demikian, keseimbangan ini dapat bergeser ketika produksi radikal bebas meningkat. Stres oksidatif dihasilkan dari ketidakseimbangan antara produksi radikal bebas dan sistem peredam radikal, baik peningkatan produksi radikal bebas atau penurunan aktivitas antioksidan pertahanan atau keduanya (Kangralkar et al., 2010). Penelitian ini dilakukan untuk mengetahui kadar peroksida lipid dalam bentuk MDA dan mengetahui aktivitas superoksida dismutase (SOD) sebagai indikator adanya stres oksidatif pada penderita diabetes melitus tipe 2. Pemilihan pengukuran aktivitas SOD dikarenakan superoksida dismutase (SOD) merupakan garis pertahanan terdepan terhadap senyawa radikal bebas.

\section{BAHAN DAN METODE}

\section{WAKTU DAN LOKASI PENELITIAN}

Pengambilan sampel darah penderita diabetes melitus tipe 2, sampel darah normal, dan pengukuran kadar glukosa darah dilakukan di Rumah Sakit Umum Daerah Kabupaten Bekasi. Pengukuran aktivitas superoksida dismutase (SOD) dilakukan di Laboratorium Fisiologi Fakultas Matematika dan Ilmu Pengetahuan Alam, Universitas Negeri Jakarta, Indonesia, sedangkan pengukuran kadar peroksida lipid dilakukan di Laboratorium Biokimia Fakultas Kedokteran Universitas Indonesia, Indoensia. Penelitian di lakukan pada bulan Juni-Oktober 2014.

\section{ALAT DAN BAHAN}

Alat dan bahan yang digunakan pada penelitian ini terdiri dari terumo $5 \mathrm{ml}$, mikrotube, mikropipet, mikrotips, sentrifuge, kotak pendingin, kuvet, spektrofotometer, tabung sampel, tabung non EDTA, needle holder, wing needle, vacutainer, alkohol swab, plester, Konelab 20xt, Reagen uji glukosa, Kit Reagen SOD, xanthin oxidase, larutan TBA, larutan TEP, larutan TCA, larutan PBS, aquades, serum darah, es batu.

\section{PROSEDUR PENELITIAN}

Metode penelitian yang diterapkan dalam penelitian ini adalah metode Ex Post Fact, dengan desain crosssectional. Sampel yang digunakan dalam penelitian ini adalah serum darah dari 15 pasien diabetes melitus tipe 2 di RSUD Kabupaten Bekasi dan 15 orang normal yang memenuhi kriteria antara lain: berusia 40-65 tahun, memiliki tekanan darah normal, tidak ada gangguan hati dan ginjal, dan bersedia secara suka rela menjadi responden. Melakukan 
pengambilan sampel darah vena penderita diabetes melitus tipe 2 dan normal yang sebelumnya telah puasa \pm 10 jam sebanyak $5 \mathrm{~mL}$, memasukkan ke tabung non EDTA (Ethylene Diamine Tetra Acetate), kemudian mensentrifugasi sampel darah pada kecepatan 3000 rpm selama 15 menit untuk memisahkan cairan dengan sel darah, selanjutnya mengambil serum, dan menyimpan pada suhu $-20^{\circ} \mathrm{C}$ sebelum pengukuran parameter dilakukan.

Sebanyak $500 \mu \mathrm{L}$ serum dimasukkan ke dalam tabung sampel untuk diuji kadar glukosa darah. Tabung sampel selanjutnya dimasukkan ke dalam alat Konelab 20xt, yang sebelumnya telah diberi reagen uji glukosa darah. Membuat 6 larutan standar yakni S1-S6 dari standar CAL untuk membuat kurva standar. Pengukuran sampel uji dilakukan dengan mencampurkan $50 \mu \mathrm{L}$ sampel serum darah yang telah diencerkan dan $1700 \mu \mathrm{L}$ Mixed Substrate (R1), kemudian dicampur hingga homogen, selanjutnya menambahkan $250 \mu \mathrm{L}$ Xanthine Oxidase (R2) dan dilakukan pembacaan nilai serapan awal sampel pada 30 detik pertama (A1) dan nilai serapan akhir setelah 3 menit (A2) pada panjang gelombang $505 \mathrm{~nm}$.

Membuat larutan standar tetraetoksipropan (TEP) dengan 6 konsentrasi untuk membuat kurva standar. Menyiapkan serum darah yang telah diencerkan sebanyak $200 \mu \mathrm{L}$, aquades $200 \mu \mathrm{L}$, larutan Asam Trikloroasetat (TCA) 20\% $200 \mu \mathrm{L}$, masing-masing bahan dibuat duplo. Mencampur bahan dan mengaduknya hingga homogen. Mensentrifugasi sampel dengan kecepatan 3500 rpm selama 10 menit. Mengambil supernatan yang dihasilkan. Menambahkan larutan asam tiobarbiturat (TBA) $0,67 \%$ sebanyak $400 \mu \mathrm{L}$ dan mencampur hingga homogen. Memanaskan pada penangas suhu $96-1000 \mathrm{C}$ selama 10 menit. Mengangkat sampel dari penangas kemudian mendinginkan di suhu ruang selama 15 menit. Membaca serapan pada panjang gelombang $530 \mathrm{~nm}$.

\section{ANALISIS DATA}

Kadar MDA dan aktivitas SOD yang dari masing-masing kelompok pasien penderita diabetes dan pasien normal dibandingkan secara statistik dengan uji Mann Whiteney. Untuk mengetahui pada kelompok mana yang lebih tinggi kadar MDA dan aktivitas SOD diantara kedua kelomopk tersebut, maka kami sajikan data rata-rata dan simpangan eror dari kadar MDA dan aktivitas SOD dari kedua kelompok. Mengingat bahwa kadar MDA pada tubuh manusia merupakan respon adaptif dari tingginnya kontaminasi radikal bebas dalam tubuh dan jika radikal bebas tersebut merusak jaringan maka akan diikuti meningkatnya aktioksidan tubuh salah satunya adalah SOD, dengan demikian peningkatan MDA pada tubuh manusia pasti akan diiringi dengan menignkatnya aktivitas SOD. Untuk menguji hipotesis tersebut, kami menggunakan uji Spearman Rank untuk melihat korelasi antara kadar MDA dengan aktivitas SOD.

Tabel 1. Karakteristik Umum Subjek Penelitian

\begin{tabular}{lll}
\hline Karakteristik & DM 2 & Normal \\
\hline Responden & 15 & 15 \\
Jenis Kelamin & $5 / 10$ & $5 / 10$ \\
Usia, tahun & $53,40 \pm 8,21$ & $45,67 \pm 6,57$ \\
IMT, kg/m2 & $25,03 \pm 2,88$ & $24,94 \pm 2,91$ \\
Kadar Glukosa Puasa, mg/dL & $155,47 \pm 46,15$ & $86,07 \pm 9,83$ \\
\hline
\end{tabular}

\section{HASIL}

Berdasarkan tabel 1, diketahui bahwa subjek penelitian terdiri dari 5 laki-laki dan 10 perempuan baik pada kelompok penderita diabetes melitus tipe 2 maupun kelompok normal. Rata-rata usia subjek penelitian pada

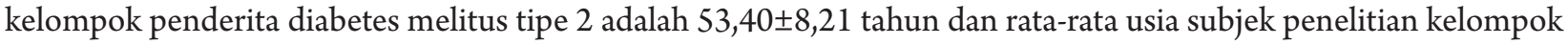


normal adalah 45,67 $\pm 6,57$ tahun. Rata-rata indeks masa tubuh (IMT) pada subjek penderita diabetes melitus tipe 2 adalah $25,03 \pm 2,88 \mathrm{~kg} / \mathrm{m} 2$ dan rata-rata IMT pada subjek penelitian kelompok normal adalah 24,94 $\pm 2,91 \mathrm{~kg} /$ $\mathrm{m} 2$. Rata-rata kadar glukosa darah puasa subjek penelitian pada kelompok penderita diabetes melitus tipe 2 adalah $155,47 \pm 46.15 \mathrm{mg} / \mathrm{dL}$ dan rata-rata kadar glukosa darah puasa pada kelompok normal adalah 86,07 $\pm 9.83 \mathrm{mg} / \mathrm{dL}$.

Tabel 2. Data Sekunder Penderita Diabetes Melitus

\begin{tabular}{lll}
\hline \multirow{2}{*}{ Informasi } & \multicolumn{2}{c}{ Penderita DM } \\
\cline { 2 - 3 } & $\mathrm{N}$ & $\%$ \\
\hline Riwayat Keturunan DM (YA/ TIDAK) & $6 / 9$ & $40 / 60$ \\
Riwayat Merokok (YA/ TIDAK) & $3 / 12$ & $20 / 80$ \\
Keluarga Perokok (YA/ TIDAK) & $9 / 6$ & $60 / 40$ \\
Penggunaan Kendaraan Bermotor (SERING/ JARANG) & $10 / 5$ & $66,7 / 33,3$ \\
Konsumsi Junk Food (SERING/ JARANG) & $3 / 12$ & $20 / 80$ \\
Konsumsi Sayur (SERING/ JARANG) & $13 / 2$ & $86,7 / 13,3$ \\
Konsumsi Buah (SERING/ JARANG) & $12 / 3$ & $80 / 20$ \\
Aktivitas Olahraga (SERING/ JARANG) & $6 / 9$ & $40 / 60$ \\
\hline
\end{tabular}

Tabel 3. Hasil uji beda rata-rata kadar MDA dan aktivitas SOD

\begin{tabular}{llll}
\hline Variabel & DM 2 & Normal & $\mathrm{p}$ \\
\hline Kadar MDA $(\mathrm{nMol} / \mathrm{mL})$ & $1,06 \pm 0,21$ & $0,64 \pm 0,10$ & 0,00 \\
Aktivitas SOD $(\mathrm{U} / \mathrm{mL})$ & $1,01 \pm 2,29$ & $0,79 \pm 1,01$ & 0,29 \\
\hline
\end{tabular}

Tabel 2 menunjukkan informasi data sekunder penderita DM 2, dapat dilihat bahwa sebanyak $40 \%$ penderita memliki keturunan DM di keluarga. Kemudian sebanyak 80\% penderita tidak memiliki riwayat merokok, namun $60 \%$ penderita mengatakan bahwa terdapat keluarga yang merokok di rumahnya. Penggunaan kendaraan bermotor sebanyak $66,7 \%$ penderita mengaku sering menggunakan kendaraan bermotor. Kemudian sebanyak $80 \%$ penderita menyatakan jarang mengkonsumsi junk food, $86,7 \%$ menyatakan sering mengkonsumsi sayur, dan $80 \%$ sering mengkonsumsi buah. Sebesar $60 \%$ penderita menyatakan jarang melakukan aktivitas olahraga.

Data sekunder seperti penggunaan kendaraan bermotor dan riwayat merokok untuk mengetahui ada tidaknya paparan asap kendaraan dan asap rokok yang diterima penderita diabetes melitus tipe 2. Data sekunder mengenai konsumsi sayur dan buah untuk mengetahui asupan yang berpotensi sebagai antioksidan eksogen. Tabel 3 menunjukkan rata-rata kadar MDA serum darah pada penderita diabetes melitus tipe 2 adalah 1,06 $\pm 0,21 \mathrm{nMol} / \mathrm{mL}$, sedangkan rata-rata kadar MDA serum darah pada kelompok normal adalah 0,64 $\pm 0,10 \mathrm{nMol} / \mathrm{mL}$. Hasil tersebut menunjukkan bahwa nilai rata-rata kadar MDA serum darah pada penderita diabetes melitus tipe 2 lebih besar dari nilai rata-rata kelompok normal $(1,06>0,64)$, dengan nilai signifikansi 0,00 . Oleh karena nilai signifikansi $<\alpha=0,05$ maka dapat disimpulkan bahwa terdapat perbedaan rata-rata yang signifikan antara kadar MDA serum darah pada kelompok penderita diabetes melitus tipe 2 dengan kelompok normal.

Rata-rata aktivitas SOD serum darah pada penderita diabetes melitus tipe 2 adalah 1,01 $\pm 2,29 \mathrm{U} / \mathrm{mL}$, sedangkan rata-rata aktivitas SOD serum darah pada kelompok normal adalah 0,79 $\pm 1,01 \mathrm{U} / \mathrm{mL}$. Hasil tersebut menunjukkan bahwa nilai rata-rata aktivitas SOD serum darah pada penderita diabetes melitus lebih besar dari pada nilai rata-rata aktivitas SOD pada kelompok normal $(1,01>0,79)$ dengan nilai $\mathrm{p}=0,29$. Nilai signifikansi $>\alpha=0,05$ maka dapat disimpulkan bahwa tidak terdapat perbedaan signifikan antara rata-rata aktivitas SOD serum darah pada penderita diabetes melitus tipe 2 dengan kelompok normal. 
Tabel 4. Hasil Uji Korelasi antara Kadar MDA dan Aktivitas SOD dengan Spearman's Correlation

\begin{tabular}{lll}
\hline Kelompok & Signifikansi $(\mathrm{p})$ & Koef. Korelasi $(\mathrm{rs})$ \\
\hline DM 2 & 0,478 & 0,199 \\
Normal & 0,194 & 0,355 \\
\hline
\end{tabular}

Pada tabel 4, menunjukkan bahwa antara kadar MDA dengan aktivitas SOD serum darah pada penderita diabetes melitus tipe 2 memiliki nilai rs = 0,199 yang dapat dikategorikan memiliki kekuatan korelasi sangat lemah dan korelasi positif (berbanding lurus) artinya jika kadar MDA pada serum darah penderita diabetes melitus tipe 2 tinggi maka aktivitas SOD juga akan meningkat. Berdasarkan uji signifikasi hasilnya menunjukkan nilai $\mathrm{p}=0,478>0,05$ maka H0 diterima artinya tidak terdapat hubungan signifikan antara kadar MDA dan aktivitas SOD serum darah pada penderita diabetes melitus tipe 2 .

Pada kelompok normal, hasil yang didapat yakni antara kadar MDA dengan aktivitas SOD serum darah pada kelompok normal memiliki nilai rs= 0,355 yang dapat dikategorikan memiliki kekuatan korelasi cukup dan korelasi positif (berbanding lurus) artinya jika kadar MDA serum darah tinggi maka aktivitas SOD juga akan meningkat. Berdasarkan uji signifikasi hasilnya menunjukkan nilai $\mathrm{p}=0,194>0,05$ maka H0 diterima artinya tidak terdapat hubungan signifikan antara kadar MDA dan aktivitas SOD serum darah pada kelompok normal. Selanjutnya dilakukan uji beda koefisien korelasi antara kadar MDA dan aktivitas SOD pada penderita diabetes melitus tipe 2 dan normal. Nilai koefisien korelasi diperoleh dari uji Spearman's Correlation. Uji beda koefisien korelasi ini dilakukan dengan menggunakan software Medical Calculator, kemudian setelah dilakukan uji beda koefisien korelasi ternyata diperoleh hasil yakni tidak terdapat perbedaan koefisien korelasi yang signifikan antara keduanya dengan nilai $\mathrm{p}=$ $0,6781>0,05$.

\section{PEMBAHASAN}

\section{KARAKTERISTIK UMUM SUBJEK PENELITIAN}

Pada penelitian ini diketahui bahwa rata-rata usia kelompok penderita diabetes melitus tipe 2 yakni $53,40 \pm 8,21$ tahun, rata-rata usia ini lebih tua dibanding rata-rata usia pada kelompoknormal. Seperti yang disebutkan oleh Bustan (2007) salah satu faktor risiko utama diabetes melitus tipe 2 adalah usia $>45$ tahun. Peningkatan resiko diabetes seiring dengan usia, khususnya pada usia lebih dari 40 tahun disebabkan karena pada usia tersebut mulai terjadi peningkatan intoleransi glukosa. Adanya proses penuaan menyebabkan berkurangnya kemampuan sel beta pankreas dalam memproduksi insulin.

Rata-rata indeks massa tubuh (IMT) pada subjek penelitian kelompok penderita diabetes melitus tipe 2 yakni sebesar $25,03 \pm 2,88 \mathrm{~kg} / \mathrm{m}^{2}$, rata-rata tersebut lebih besar dibanding dengan rata-rata pada kelompok normal. Seperti yang disebutkan oleh Bustan (2007) bahwa obesitas (dengan IMT $>25 \mathrm{~kg} / \mathrm{m}^{2}$ ) juga merupakan faktor risiko utama diabetes melitus tipe 2. Hal ini sejalan dengan penelitian Sujaya (2009), bahwa individu yang mengalami obesitas mempunyai risiko lebih besar untuk terkena diabetes melitus dibandingkan dengan individu yang tidak mengalami obesitas. Obesitas akan menyebabkan meningkatnya asam lemak dalam sel. Peningkatan asam lemak ini akan menurunkan translokasi transporter glukosa ke membran sel, dan menyebabkan terjadinya resistensi insulin pada jaringan otot dan adiposa (Garnita, 2012).

Rata-rata kadar glukosa darah puasa subjek penelitian pada kelompok penderita diabetes melitus tipe 2 adalah155,47 $\pm 46.15 \mathrm{mg} / \mathrm{dL}$ dan rata-rata kadar glukosa darah puasa pada kelompok normal adalah 86,07 \pm 9.83 
$\mathrm{mg} / \mathrm{dL}$. Sebelum dilakukan pengukuran kadar glukosa darah, setiap subjek penelitian diharuskan menjalani puasa selama 10-12 jam. Hal ini bertujuan agar glukosa darah yang terukur tidak terganggu dengan kadar glukosa yang berasal dari asupan makanan sehingga nilai kadar glukosa yang diperoleh dapat lebih akurat. Selama menjalani puasa 10-12 jam, subjek penelitian hanya diperbolehkan untuk minum air putih. Diabetes melitus ditandai jika hasil pemeriksaan glukosa darah puasa $10 \mathrm{jam} \geq 126 \mathrm{mg} / \mathrm{dL}$ (ADA, 2012). Menurut Guyton (2008) mekanisme dalam mengatur kadar glukosa darah melibatkan peran hormon insulin dan glukagon, sebagai sistem pengatur umpan balik dalam mempertahankan glukosa darah tetap normal. Insulin adalah hormon yang disekresi oleh sel beta pankreas di pulau Langerhans dan memiliki peran penting dalam regulasi metabolisme karbohidrat. Efek insulin pada metabolisme karbohidrat yakni insulin mempercepat difusi terfasilitasi glukosa ke dalam sel di hampir semua jaringan (kecuali otak) dan menurunkan kadar glukosa darah (Unal et al., 2012).

Pada diabetes melitus tipe 2 terjadi gangguan metabolisme glukosa disebabkan oleh resistensi insulin yang disertai defisiensi insulin. Pada penderita tipe ini, insulin tetap dihasilkan namun terjadi penurunan kemampuan insulin untuk bekerja pada jaringan target perifer (terutama otot dan hati). Insulin yang ada tidak bekerja dengan baik karena reseptor insulin pada sel berkurang atau berubah struktur sehingga hanya sedikit glukosa yang berhasil masuk sel. Hal ini menyebabkan kadar glukosa darah pada penderita diabetes melitus tipe 2 tetap dalam keadaan yang tinggi.

PERBANDINGAN KADAR MDA DAN AKTIVITAS SOD RATA-RATA PADA PENDERITA DIABETES MELITUS TIPE 2 DAN NORMAL.

Kadar MDA serum diperoleh dari 15 orang penderita diabetes melitus tipe 2 dan 15 orang normal. Berdasarkan tabel 4, terlihat perbedaan yang signifikan antara rata-rata kadar MDA serum darah pada kelompok penderita diabetes melitus tipe 2 dengan kelompok normal, dimana rata-rata kadar MDA serum pada kelompok penderita $(1,06 \pm 0,21 \mathrm{nMol} / \mathrm{mL})$ lebih tinggi dibandingkan dengan kelompok normal $(0,64 \pm 0,10 \mathrm{nMol} / \mathrm{mL})$. Hasil penelitian ini sesuai dengan penelitian yang dilakukan Hong-zhi Panet al. (2009) yakni terjadi peningkatan kadar MDA serum yang ditemukan pada penderita diabetes melitus. Hong-zhi Pan et al. (2009) melaporkan bahwa penderita diabetes melitus secara signifikan memiliki kadar MDA yang lebih besar $(6,30 \pm 2,32 \mathrm{nMol} / \mathrm{mL})$ dibandingkan dengan subjek kontrol (3,16 $\pm 1,21 \mathrm{nMol} / \mathrm{mL})$. Selain itu Samuel et al. (2010) juga menyebutkan bahwa konsentrasi MDA secara signifikan lebih besar $(4,73 \pm 0,51 \mathrm{nMol} / \mathrm{mL})$ pada kelompok diabetes tipe 2 dibandingkan pada kontrol $(3,83 \pm 0,26 \mathrm{nMol} / \mathrm{mL})$.

Seperti yang diketahui, radikal bebas diproduksi secara terus-menerus didalam tubuh sebagai hasil sampingan dari proses metabolisme sel normal, namun beberapa kondisi diketahui dapat mengganggu keseimbangan antara produksi radikal bebas dan mekanisme pertahanan sel (Moussa, 2008). Pada proses respirasi mitokondria, molekul oksigen penting untuk melengkapi metabolisme glukosa dan substrat lain selama produksi ATP. Proses respirasi akan menghasilkan produk sampingan berupa radikal bebas superoksida, hal ini karena selama rangkaian fosforilasi oksidatif normal sekitar 2-4\% dari semua oksigen yang dikonsumsi dikonversi menjadi radikal bebas superoksida (Evans et al., 2002).

Pada hasil penelitian ini, kadar MDA penderita diabetes melitus tipe 2 lebih tinggi dibanding normal. Hal ini diduga karena pada penderita diabetes melitus terjadi kondisi hiperglikemia atau tingginya kadar glukosa dalam darah. Berdasarkan data pada tabel 2, diketahui bahwa rata-rata kadar glukosa pada kelompok penderita diabetes melitus tipe 2 yakni $155 \mathrm{mg} / \mathrm{dL}$, lebih tinggi dari kelompok normal. Menurut Moussa (2008), kondisi hiperglikemia 
yang persisten pada diabetes akan menyebabkan produksi radikal bebas berlebihan didalam tubuh khususnya ROS. Ada banyak jenis radikal bebas, tetapi yang paling banyak dalam sistem biologis tubuh adalah radikal yang berasal dari oksigen dan dikenal sebagai ROS. Radikal bebas terdiri dari Reactive Oxygen Species (ROS), Radical Nitrogen Species (RNS), dan radikal lainnya. Peningkatan glukosa akan menyebabkan stres oksidatif karena adanya peningkatan ROS mitokondria, glikasi protein non enzimatik, dan autooksidasi glukosa (Evans et al., 2002).

Radikal bebas dalam jumlah yang berlebih didalam tubuh akan mengambil elektron dari lipid yang berada di membran sel, sehingga terjadi peroksidasi lipid. Malondialdehida (MDA) merupakan biomarker atau penanda biologi yang digunakan secara luas dan merupakan produk akhir dari peroksidasi lipid. Sejumlah konsekuensi fisiologi merugikan dari peningkatan kadar MDA termasuk diantaranya kebocoran membran sel dengan mengubah struktur membran, menginaktivasi membran berikatan dengan enzim, serta menginaktivasi reseptor molekul permukaan menuju gangguan regulasi sel (Mahreen et al., 2010). Menurut Widowati (2005), senyawa radikal bebas merupakan produk samping metabolisme normal tubuh. Radikal bebas juga dihasilkan ketika tubuh terpapar polusi lingkungan seperti asap rokok, asap kendaraan, bahan pencemar, toksin, pestisida, radiasi matahari, radiasi ultraviolet, dan peningkatan konsumsi makanan yang mengandung asam lemak tidak jenuh.

Berdasarkan data sekunder penderita diabetes melitus tipe 2, sebesar $20 \%$ penderita memiliki riwayat pernah merokok dan sebanyak $60 \%$ penderita juga memiliki anggota keluarga yang merokok. Selain itu, sebanyak $66,7 \%$ penderita juga mengaku sering menggunakan kendaraan bermotor untuk aktvitasnya. Hal ini menandakan bahwa penderita diabetes terpapar asap dari rokok dan asap kendaraan bermotor. Seperti diketahui bahwa asap rokok dan asap kendaraan merupakan salah satu sumber eksogen radikal bebas (Widowati, 2005). Peningkatan senyawa radikal bebas pada perokok dapat disebabkan oleh: molekul dalam asap rokok fase tar dan gas, aktivasi makrofag dan neutrofil, dan senyawa radikal oksigen endogen yang terbentuk saat reaksi rantai pernafasan dalam mitokondria. Asap rokok mengakibatkan stres oksidatif ditandai dengan meningkatnya radikal oksidan (Komala, 2011). Hasil penelitian Bhutia et al. (2011) juga melaporkan bahwa kadar MDA serum secara signifikan lebih tinggi pada kelompok yang terkena paparan rokok.

Dalam keadaan normal radikal bebas yang dihasilkan dalam tubuh tersebut dapat diredam karena tubuh dilengkapi oleh seperangkat sistem pertahanan antioksidan. Antioksidan merupakan senyawa yang diperlukan tubuh untuk menetralisir radikal bebas dan mencegah kerusakan yang ditimbulkan oleh radikal bebas (Samueletal.,2010). Antioksidan dalam pengertian kimia adalah senyawa pemberi elektron sedangkan pengertian biologis antioksidan adalah semua senyawa yang dapat meredam radikal bebas dan ROS (Widowati, 2005). Sistem antioksidan tubuh sebagai mekanisme perlindungan terhadap serangan radikal bebas secara alami telah ada di dalam tubuh terdiri dari banyak komponen diantaranya superoksida dismutase, glutation peroksidase, katalase, dan antioksidan ekstraseluer yang berasal dari makanan seperti $\alpha$-tokoferol, $\beta$-karoten, vitamin c, ubiquinol, dan flavonoid (Widowati, 2005). Diantara antioksidan yang paling penting yang mampu memperbaiki efek stres oksidatif adalah enzim superoksida dismutase (SOD). Enzim SOD merupakan bagian dari garis pertahanan pertama dalam melawan radikal bebas (Taheri et al., 2012).

Pengujian aktivitas superoksida dismutase (SOD) merupakan salah satu parameter untuk mengetahui adanya aktivitas antioksidan. Prinsip dasar pengukuran aktivitas superoksida dismutase (SOD) adalah reaksi antara xantin dan xantin oksidase yang digunakan menghasilkan radikal superoksida. Superoksida dismutase (SOD) mengkatalis dismutasi radikal superoksida menjadi hidrogen peroksida yang bersifat lebih stabil (Widowati, 2005). Hasil penelitian menunjukkan bahwa tidak terdapat perbedaan signifikan antara aktivitas SOD pada 
penderita diabetes melitus dan normal. Namun, hasil menunjukkan bahwa aktivitas SOD cenderung lebih tinggi pada penderita diabetes melitus tipe $2(1,01 \pm 2,29 \mathrm{U} / \mathrm{mL})$ dibanding dengan normal $(0,79 \pm 1,01 \mathrm{U} / \mathrm{mL})$. Hasil ini sejalan dengan hasil penelitian Moussa (2008) yang melaporkan rata-rata aktivitas SOD penderita diabetes melitus lebih tinggi $(3820 \pm 770 \mathrm{U} / \mathrm{gHb})$ dibanding dengan normal $(1321 \pm 250 \mathrm{U} / \mathrm{gHb})$. Penelitian yang dilakukan Likidlilid et al. (2010) juga melaporkan bahwa aktivitas SOD pada penderita diabetes melitus meningkat tetapi tidak signifikan ketika dibandingkan dengan normal.

Pada penderita diabetes melitus terjadi keadaan hiperglikemia yang akan menyebabkan produksi radikal bebas khususnya ROS melalui beberapa mekanisme (Moussa, 2008). Produksi radikal bebas yang berlebihan akan memicu terjadinya stres oksidatif, yaitu suatu keadaan dimana kadar MDA yang diproduksi melebihi sistem pertahanan antioksidan enzim tubuh untuk menangkalnya. Dengan adanya peningkatan paparan radikal bebas, enzim SOD sebagai salah satu antioksidan endogen akan meningkat aktivitasnya untuk meredam efek dari radikal bebas tersebut. Hasil ini juga konsisten dengan hasil dari Dominguez et al. (1998), yang melaporkan sebuah peningkatan antioksidan enzim seperti SOD dan GPx pada diabetes melitus yang memberikan bukti adanya peningkatan produksi ROS (Reactive Oxygen Species).

Tidak adanya perbedaan yang signifikan antara aktivitas SOD pada serum darah penderita diabetes melitus dan normal diduga dipengaruhi karena adanya pengaruh antioksidan eksogen yang dikonsumsi oleh penderita diabetes melitus. Seperti yang diketahui berdasarkan data sekunder yang ditampilkan pada tabel 3, sekitar $80 \%$ penderita diabetes melitus mengaku sering mengkonsumsi sayur dan buah. Antioksidan banyak terdapat dalam buah-buahan,sayur-sayuran dan bahan pangan lainnya. Beberapa contoh antioksidan pada buah adalah polifenol, vitamin C, vitamin A, B, E, dan karotenoid. Senyawa antioksidan alami tumbuhan yaitu tokoferol, vitamin C, betakaroten, dan seyawa fenolik. Efek antioksidan terutama disebabkan karena adanya senyawa fenol seperti flavonoid dan asam fenolat. Flavonoid merupakan senyawa yang paling banyak terdapat pada tanaman dan aktivitas antioksidannya tergantung pada struktur molekul terutama gugus prenil. Tingginya konsumsi sayur dan buah diketahui dapat meningkatkan antioksidan plasma (Cao, 1998). Adanya asupan antioksidan eksogen dari sayur dan buah memungkinkan tetap terjaganya keseimbangan antara oksidan dan antioksidan, meskipun diketahui bahwa kadar MDA pada penderita diabetes melitus tipe 2 penelitian ini tinggi.

HUBUNGAN KADAR MDA DENGAN AKTIVITAS SOD SERUM DARAH PENDERITA DIABETES MELITUS TIPE 2 DAN NORMAL.

Berdasarkan hasil uji statistik, terdapat korelasi positif namun tidak signifikan antara kadar MDA dengan aktivitas SOD pada kedua kelompok. Artinya, jika kadar MDA pada serum darah tinggi maka aktivitas SOD akan meningkat. Pada kelompok penderita antara kadar MDA dan aktivitas SOD memiliki kekuatan hubungan yang sangat lemah, sedangkan pada kelompok normal memiliki kekuatan hubungan yang cukup. Hasil ini didukung dengan hasil penelitian Moussa (2008) yang menyebutkan terdapat korelasi positif antara aktivitas SOD dan kadar MDA, hal ini juga sejalan dengan hasil penelitian Dominguez (1998) yang melaporkan adanya peningkatan enzim antioksidan seperti SOD seiring adanya peningkatan produksi ROS.

Peningkatan kadar MDA dan aktivitas antioksidan enzim memperlihatkan bahwa penderita diabetes terpapar stres oksidatif melalui peningkatan peroksidasi lipid. Antioksidan enzim memiliki peran penting dalam mengurangi ROS yang terbentuk selama stres oksidatif. Namun, terdapat beberapa laporan yang berlawanan terkait aktivitas antioksidan enzim/ Pada beberapa penelitian sejenis lainnya menunjukkan adanya hasil berbeda terkait 
aktivitas SOD seperti meningkat, menurun, dan tidak berubah (Likdilid et al., 2010). Stres oksidatif merupakan hasil dari ketidakseimbangan antara produksi radikal bebas dan sistem penangkapan radikal, yaitu peningkatan produksi radikal bebas atau penurunan aktivitas pertahanan antioksidan atau keduanya. Tingginya stres oksidatif ditunjukkan oleh rendahnya status antioksidan seluler, didukung oleh tingginya produk peroksidasi lipid (Winarsi et al., 2012).

Pada hasil penelitian ini menunjukkan peningkatan kadar MDA pada penderita diabetes melitus tipe 2 diikuti dengan peningkatan aktivitas SOD, sehingga diduga pada penderita diabetes melitus tipe 2 belum terjadi stres oksidatif. Hal ini mungkin terjadi karena penderita diabetes melitus tipe 2 yang menjadi responden penelitian ini rata-rata belum lama menderita penyakit diabetes melitus. Berdasarkan data sekunder hasil wawancara diketahui bahwa dari 15 responden sebanyak 11 responden mengatakan baru menderita diabetes melitus selama $\leq 6$ tahun dan 4 sisanya mengaku telah menderita diabetes selama lebih dari 10 tahun.

Data mengenai lama menderita diabetes melitus tersebut, diduga juga dapat mempengaruhi aktivitas SOD. Sebagian besar penderita diabetes yang menjadi responden baru menderita diabetes selama kurang dari 6 tahun, hal ini diduga menyebabkan belum terjadinya kondisi stres oksidatif karena antioksidan enzim yang terdapat dalam tubuh seperti SOD masih dapat bekerja dengan baik dalam mengatasi radikal bebas. Kerusakan oksidatif ditandai dengan adanya peningkatan MDA yang diikuti dengan penurunan aktivitas SOD (Zanuri et al., 2012). Hasil korelasi positif yang diperoleh pada penderita diabetes melitus tipe 2, diduga juga dipengaruhi karena adanya antioksidan eksogen yang berasal dari asupan makanan sayur dan buah yang dilakukan oleh penderita diabetes melitus. Hal ini menyebabkan sekalipun kadar MDA pada penderita diabetes melitus tinggi, aktivitas antioksidan yang berperan dalam mengatasi radikal bebas tetap tercukupi. Pada sayur-sayuran dan buah-buahan banyak ditemukan senyawa flavonoid dan dilaporkan sebagai antioksidan berpotensi lebih kuat dibandingkan dengan vitamin $\mathrm{C}$ dan $\mathrm{E}$. Selain flavonoid, senyawa lain pada sayuran yang berperan sebagai antioksidan yakni isoflavon. Beberapa peneliti melaporkan bahwa isoflavon berperan meningkatkan aktivitas SOD (Winarsi, 2007).

Adanya hubungan yang tidak bermakna atau tidak signifikan diduga dikarenakan adanya antioksidan lain yang bekerja didalam tubuh selain SOD. Antioksidan enzim yang bekerja didalam tubuh diantaranya superoksida dismutase (SOD), glutation peroksidase (GPx), katalase (CAT), dimana masing-masing antioksidan memiliki tugas berbeda dalam mengurangi efek dari radikal bebas. Pada penelitian ini, aktivitas antioksidan yang diukur hanya aktivitas antioksidan superoksida dismutase (SOD), karena SOD dianggap sebagai pertahanan primer terhadap radikal bebas. Berdasarkan hasil uji beda koefisien korelasi, diketahui bahwa tidak terdapat perbedaan yang signifikan antara hubungan kadar MDA dan aktivitas SOD serum pada penderita maupun normal. Hasil uji korelasi samasama menunjukkan korelasi positif antara kadar MDA dan aktivitas SOD, baik pada kelompok penderita diabetes melitus tipe 2 maupun normal. Hal ini menandakan bahwa aktivitas SOD masih terjaga karena kondisi stres oksidatif belum terjadi pada penderita diabetes melitus tipe 2 .

\section{KESIMPULAN}

Kesimpulan, terdapat perbedaan signifikan kadar MDA dan tidak terdapat perbedaan signifikan aktivitas SOD, terdapat korelasi postif namun tidak signifikan antara kadar MDA dengan aktivitas SOD serum darah pada diabetes melitus tipe 2 dan normal, serta tidak terdapat perbedaan signifikan antara kedua koefisien tersebut. 


\section{DAFTAR PUSTAKA}

American Diabetes Association. 2012. Diagnosis and Classification of Diabetes Melitus. Diabetes Care. 35: 564 .

Alvarez JG. 1987. Spontaneous lipid peroxidation and production of hydrogen peroxide and superoxide in human spermatozoa: superoxide as major enzyme protectant againts oxygen toxixity. J. Androl. 8: 338- 348.

Bustan, M.N. 2007. Epidemiologi: Penyakit Tidak Menular. Jakarta: Rineka Cipta.

Bhutia, Yazum., Amrita Ghosh,Mingma L. Sherpa, Ranabir Pal, Pradip Kumar Mohanta. 2011. Serum Malondialdehyde Level: Surrogate stress marker in the Sirkkimese diabetics. IJ Nat Sci Bio Med. 2(1): 107-112.

Cao, G., Booth SL, SadowskiJA., Prior RL. 1998. Increase ini human plasma antioxidant capacity after consumption of controlled diets high in fruit and vegetables. Am J Clin Nutr. 68(5):1081-7.

Dominguez, C., E.Ruiz, M.Gussinye, A. Carrascosa. 1998.Oxidative stress at onset and in early stages of type 1 diabetes in children and adolescent. Diabetes Care. 21: 1736-42.

Evans., et al. 2002. Oxidative Stress: A Unifying Hypothesis of Diabetes. Endocrine Review. 23(5): 599-622.

Garnita, Dita. 2012. “Faktor Risiko Diabetes Melitus Di Indonesia (Analisis Data Sakerti 2007)”. Skripsi. Fakultas Kesehatan Masyarakat-Universitas Indonesia.

Guyton dan Hall. 2010. Buku Saku Fisiologi Kedokteran Edisi 11. Jakarta: EGC.

Hong-zhi Pan, Lin Zhang, Mei-yi Guo. 2009. The Oxidative Stress Status in Diabetes Mellitus and diabetic nephrophathy. Acta Diabetol.

Kangralkar, V.A., Shivraj D. Patil, R. M. Bandivadekar. 2010. Oxidative Stress and Diabetes : a Review. International Journal of Pharmaceutical Applications. 1 (1):38-45.

Komala, P Setia Rahardja. 2011. "Efek Fluvastatin terhadap Selisih Jumlah Leukosit, Neutrofil, dan Alkali Fosfatase Serum pada Tikus Wistar Sebelum dan Sesudah Paparan Asap Rokok”. Tesis. Program Magister Ilmu Biomedik Universitas Diponegoro.

Kumawat, Manjulata., Manju Bala Pahwa, Veena Singh Gahlaut and Neelima Singh. 2009. Status of Antioxidant Enzymes and Lipid Peroxidation in Type 2 Diabetes Mellitus with Micro Vascular Complications. The Open Endocrinology Journal. 3: 12-15.

Likidlilid,Aatip., Natchai Patchanans. 2010. Lipid Peroxidation and AntioxidantEnxyme Activities in Erythrocytes of Type 2 Diabetic Patient. J Med Assoc Thai. 93 (6): 682-93.

Mahreen, Rashida., M. Mohsin, Zahida Nasreen, M.Siraj, M.Ishaq. 2010. Significantly increased levels of serum malonaldehyde in type 2 diabetics with myocardial infarction. Int J Diabetes Dev Ctries. 30 (1): 4951 .

Moussa, S.A. 2008. Oxidative Stress In Diabetes Mellitus. Romanian J. Biophys. 18 (3): 225-236.

Samuel, Vivian., Smilee Johncy. 2010. Evaluation of Lipid Peroxidation and Antioxidant Statusin Diabetes with and without Complications. J Biomed Sci and Res. 2 (3):162-166.

Setiawan, Bambang dan Eko Suhartono. 2005. Stres Oksidatif dan Peran Antioksidan pada Diabetes Melitus. Majalah Kedokteran Indonesia. 55 (2): 87-90. 
Sujaya, I Nyoman. 2009.Pola konsumsi makanan tradisional Bali sebagai faktor risiko diabetes melitus tipe 2 di Tabanan. Jurnal Skala Husada. 6 (1): 75-81.

Taheri, Ehsaneh., Mahmoud Djalali, Ahmad Saeisomeolia, Ali Malekshahi Moghadam, Abolghase Djazayeri, Mostafa Qorbani. 2012. The relationship between the activates of antioxidant enzymes in red blood cells and body mass index in Iranian type 2 diabetes and healthy subjects. Journal of Diabetes \& Metabolic Disorders. $11: 3$.)

Unal,Deniz. 2012. Insulin hormone: Mechanism and effects on the body and relationship with central nervous system. Dicle Medical Journal. 39 (2): 310-315.

Widia, Sri. 2009. Oxidative Stress In Liver Tissue Of Rat Induced by Chronic System Hypoxia. Makara Kesehatan. $13(1): 34-38$.

Widowati, Wahyu. 2005. Penapisan aktivitas superoksida dismutase pada berbagai tanaman. JKM. 5 (1): 33-34.

Winarsi,Hery., Siwi P M Wijayanti, Agus Purwanto. 2012. Aktivitas Enzim Superoksida Dismutase,Katalase, dan Glutation Peroksidase Wanita Penderita Sindrom Metabolik. MKB. 44 (1): 7-11.

Winarsi, Hery. 2007. Antioksidan Alami dan Radikal Bebas Cetakan ke 2. Yogyakarta: Kanisnus.

Zanuri, Masagus., Septelia Inawati Wanandi. 2012. Aktivitas Spesifik MnSOD dan Katalase pada Hati Tikus yang Dinduksi Hipoksia Sistemik: Hubungannya dengan Kerusakan Oksidatif. Media Litbang Kesehatan 22 (2): 87-92. 